\title{
The role of microfilaments and microtubules during pH-regulated morphological transition in Candida albicans
}

\author{
Koji Yokoyama, Haruo Kaji, Kazuko Nishimura and Makoto Miyaji \\ Author for correspondence: K. Yokoyama. Tel: +8143222 7171. Fax: +81432246326.
}

Department of Fungal Infections, Research Center for Pathogenic Fungi and Microbial Toxicoses, Chiba University, 1-8-1 Inohana, Chuo-ku, Chiba 260, Japan

\begin{abstract}
Yeast cells of Candida albicans produced germ tubes in a salt-glucose medium containing $4 \%$ calf serum at pH 7 and $37{ }^{\circ} \mathrm{C}$. Hyphal growth continued for $24 \mathrm{~h}$ and the filaments did not revert to yeast cells. When cells were grown at pH 4, reversion to yeast growth was observed, despite the presence of serum. The elongation of hyphae was inhibited within $\mathbf{3 0 ~} \mathrm{min}$. The distribution of microtubules and microfilaments during pH-regulated morphological transition was studied by an immunofluorescence technique using an antitubulin antibody with a FITC-conjugated secondary antibody, and by staining with tetramethylrhodaminyl phalloidin for filamentous actin and actin granules. After changing to acidic conditions, microtubules were distributed normally in the cytoplasm; however, microfilaments disappeared from hyphal cells, and actin granules were localized at the site of budding. These results show that microfilaments play an important role during pH-regulated morphological transition.
\end{abstract}

Keywords: Candida albicans, microtubules, microfilaments, $\mathrm{pH}$ regulation, morphological transition

\section{INTRODUCTION}

Candida albicans is a pathogenic and polymorphic fungus having four major morphologies, namely yeast cells, pseudohyphae, hyphae and chlamydospores. There are several major differences between the growth of yeast and filamentous forms of $C$. albicans (Yokoyama \& Takeo, 1983). The reciprocal transformations observed between the yeast and filamentous forms seems to be related to the pathogenicity of this fungus. The study of dimorphism of this fungus is useful for elucidating the mechanisms of morphogenesis, growth and differentiation.

Environmental factors are vital for control of the morphology of $C$. albicans. Temperature and $\mathrm{pH}$ produce morphological changes in amino acid-containing defined media (Lee et al., 1975; Buffo et al., 1984). The characteristics of $\mathrm{pH}$-regulated dimorphism of this fungus have been reported when defined amino acid-containing media are used (Buffo tt al., 1984). Lee's medium (lacking glucose) induced germ tubes at $\mathrm{pH} 3$ (Pollack \& Hashimoto, 1987). Changes of intracellular $\mathrm{pH}$ correlated with

Abbreviations: DAPI, 4'6-diamidino-2-phenylindole; FITC, fluorescein isothiocyanate; Rh-phalloidin, tetramethylrhodaminyl phalloidin. the dimorphic transition of this organism (Stewart et al., 1988, 1989; Kaur et al., 1988). Plasma membrane $\mathrm{H}^{+}-$ ATPase activity was monitored during $\mathrm{pH}$-regulated dimorphism of C. albicans by Kaur \& Mishra (1991). They suggested that the changes of intracellular $\mathrm{pH}$ and ATPase may play a regulatory role in dimorphism of this fungus. However, since Gupta \& Prasad (1993) reported that levels of plasma membrane $\mathrm{H}^{+}$-ATPase do not change during growth and morphogenesis of $C$. albicans, posttranslational modification(s) of enzyme protein is suggested to account for the variation in PM-ATPase activity during morphogenesis. The correlation between intracellular $\mathrm{pH}$ change and morphological change is not yet clear.

We previously reported (Yokoyama et al., 1990) that cytoplasmic microtubules are not essential for the elongation of filamentous cell tips but that microfilaments are. In this paper, we report that microfilaments play a leading role in $\mathrm{pH}$-regulated dimorphism of $C$. albicans.

\section{METHODS}

Organisms. The Candida albicans strains used, IFM (Research Center for Pathogenic Fungi and Microbial Toxicoses) 40009 (ATCC 48130), 40100, 40101 and 40102, were all clinical isolates. 

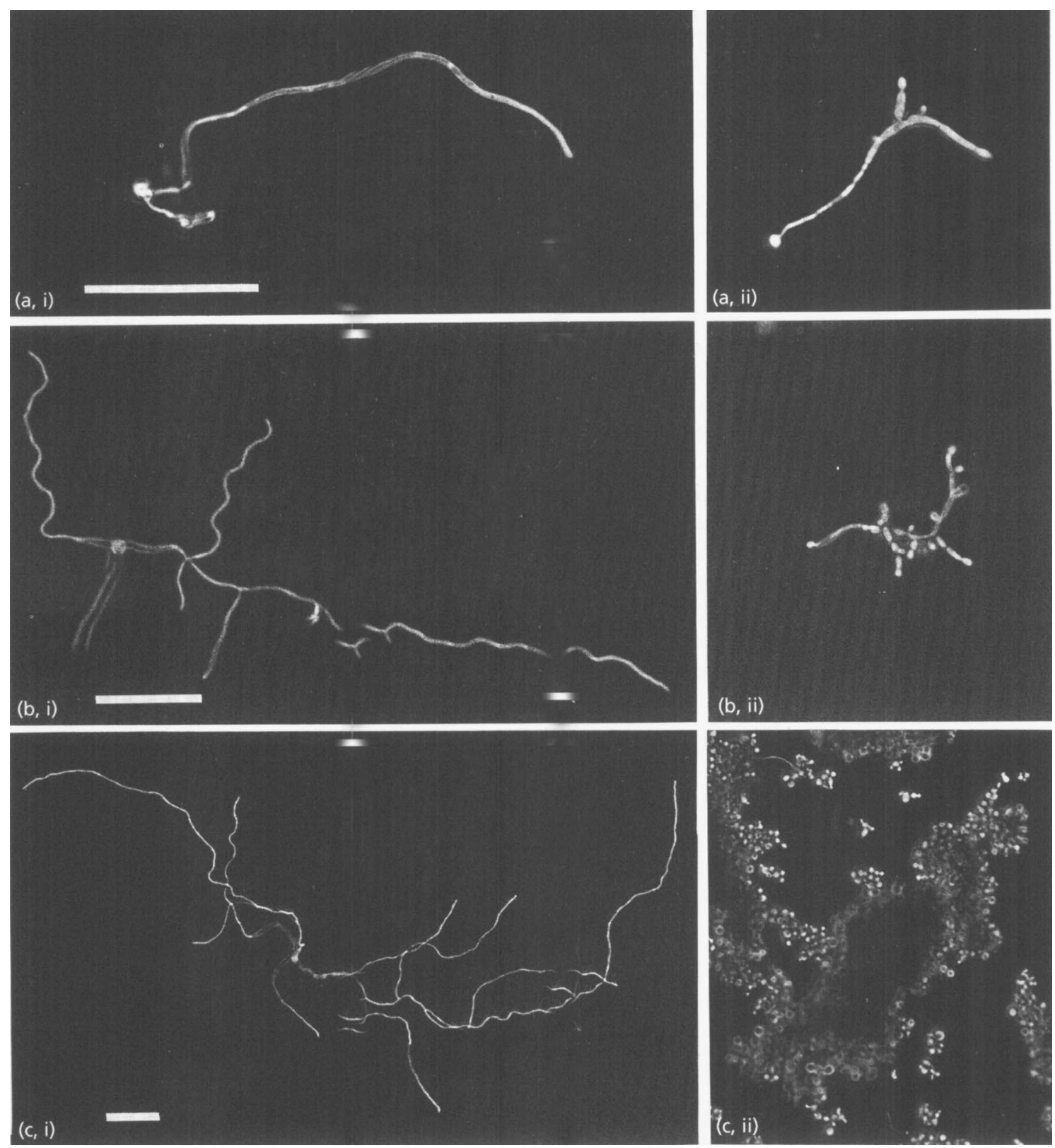

Fig. 1. Conversion of hyphal growth to yeast growth on changing the $\mathrm{pH}$ of the medium from 7 to 4 at $37^{\circ} \mathrm{C}$. Microphotographs were taken after germ tube formation at $2 \mathrm{~h}[(\mathrm{a}, \mathrm{i}), \mathrm{pH} 7$; (ii), $\mathrm{pH} 4], 6 \mathrm{~h}[(\mathrm{~b}, \mathrm{i}), \mathrm{pH} 7$; (ii), $\mathrm{pH} 4]$ and $21 \mathrm{~h}[(\mathrm{c}, \mathrm{i}), \mathrm{pH} 7$; (ii), $\mathrm{pH} 4]$ for $3 \mathrm{~h}$ at $37^{\circ} \mathrm{C}$ in HFM7. Bar, $50 \mu \mathrm{m}$.

Media and culture. Preincubation liquid medium was YPD, containing $1 \%(\mathrm{w} / \mathrm{v})$, yeast extract, $2 \%(\mathrm{w} / \mathrm{v})$ polypeptone (Wako) and $2 \%(\mathrm{w} / \mathrm{v})$ glucose. Hypha-forming medium (HFM) contained the following components per litre: glucose, $5 \mathrm{~g}$; $\mathrm{Na}_{2} \mathrm{HPO}_{4} .12 \mathrm{H}_{2} \mathrm{O}, 0.26 \mathrm{~g} ; \mathrm{KH}_{2} \mathrm{PO}_{4}, 0.66 \mathrm{~g} ; \mathrm{MgSO}_{4} .7 \mathrm{H}_{2} \mathrm{O}$, $0.08 \mathrm{~g} ; \mathrm{NH}_{4} \mathrm{Cl}, 3.3 \mathrm{~g}$; biotin $16 \mu \mathrm{g}$; calf serum (Gibco) $4 \%$ $(\mathrm{v} / \mathrm{v})$. The $\mathrm{pH}$ of HFM7 and of HFM4 was adjusted to $7 \cdot 0$ and 4.0 with $3 \mathrm{M} \mathrm{NaOH}$ and $1 \mathrm{M} \mathrm{HCl}$, respectively, and filtersterilized. Plastic Petri dishes $(30 \mathrm{~mm}$ diameter) were coated with a solution $(200 \mu \mathrm{l})$ of poly-L-lysine $\left(100 \mu \mathrm{g} \mathrm{ml} \mathrm{m}^{-1}\right.$; poly-Llysine hydrobromide, $M_{\mathrm{r}} 70000-150000$, Sigma). After $5 \mathrm{~min}$, the solution was removed by aspiration and the treated surface was rinsed twice with $1 \cdot 5-2 \cdot 0 \mathrm{ml}$ sterile, distilled and deionized water. The culture dishes were air-dried before use.

Induction of germ tubes or yeast growth. C. albicans was preincubated in YPD medium at $25{ }^{\circ} \mathrm{C}$ and magnetically stirred (about 60 r.p.m.) for $24-38 \mathrm{~h}$ (early stationary phase; about $10^{7}$ cells ml ${ }^{-1}$ ). Germ tubes were induced within $60 \mathrm{~min}$ after preincubated cells were inoculated (final $10^{4}$ cells $\mathrm{ml}^{-1}$ ) in HFM7 at $37^{\circ} \mathrm{C}$. Preincubated yeast cells did not form germ tubes at $37^{\circ} \mathrm{C}$ in HFM4 medium. HFM 7 medium was removed after $3 \mathrm{~h}$ incubation from the culture dish and HFM4 medium was added. Hyphal growth converted to yeast growth when 

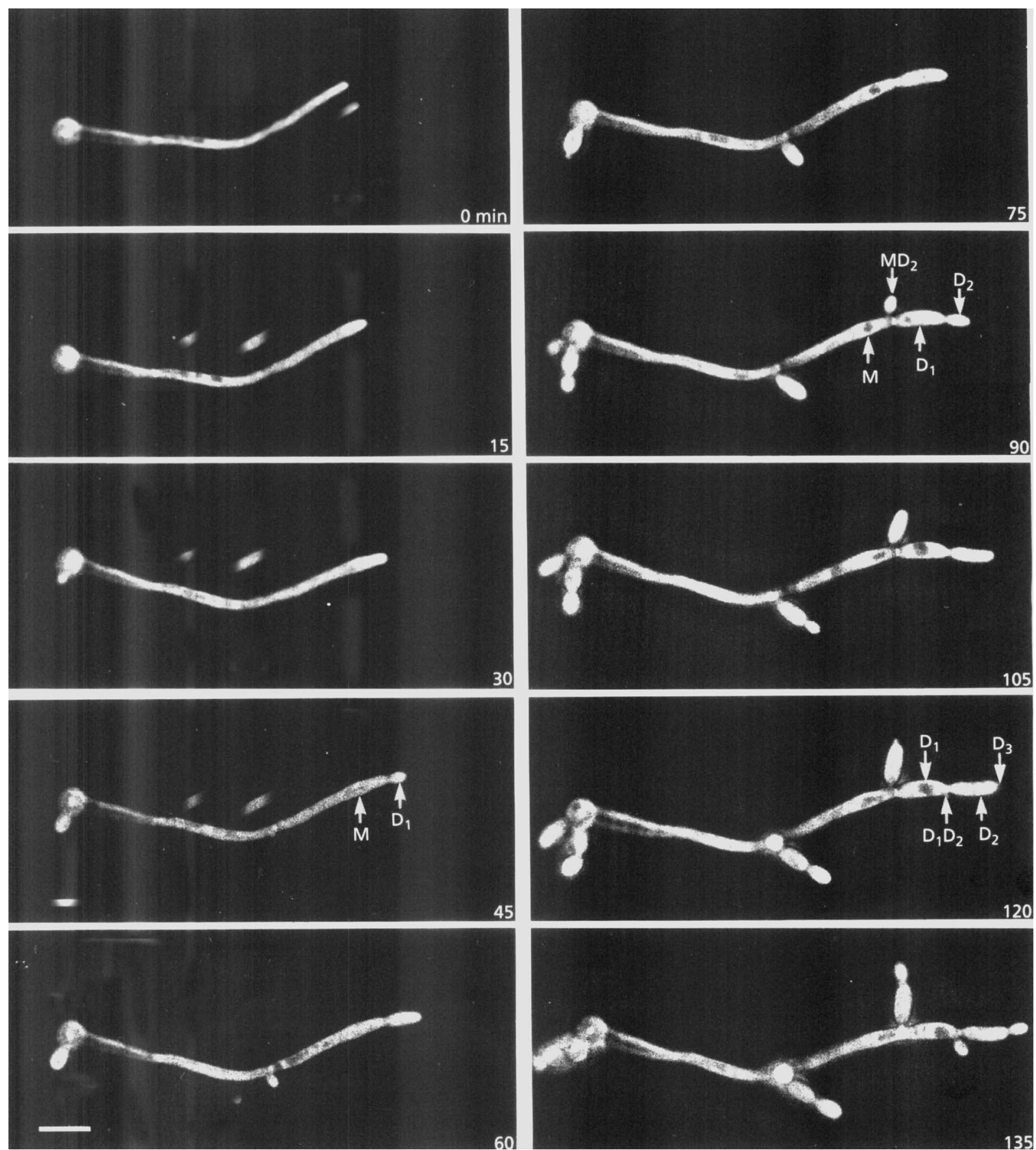

Fig. 2. Time-lapse microphotographs of $C$. albicans IFM 40009 initiated after conversion of the incubation medium to HFM4. Cells were photographed at 15 min intervals. $M$, filamentous mother cell; $D_{1}$, first daughter cell from $M_{;} D_{2}$, second daughter cell from $D_{1} ; D_{3}$, third daughter cell from $D_{2} ; \mathrm{MD}_{2}$, other daughter cell from $M_{;} D_{1} D_{2}$, new daughter cell from $D_{1}$. Inhibition of hyphal extension was observed within 30 min and yeast growth appeared at 75 min. Bar, $10 \mu \mathrm{m}$.

HFM7 medium was changed to HFM4 at $37^{\circ} \mathrm{C}$. Microphotographs were taken at 2,6 and $21 \mathrm{~h}$ after hypha formation for $3 \mathrm{~h}$ at $37^{\circ} \mathrm{C}$ in HFM7 using a Nikon TMD inverted phasecontrast microscope with Plan $\times 10$ or $\times 20 \mathrm{BM}$ objective lenses (Nippon Kogaku).

Time-lapse photomicrography. Preincubated yeast cells were incubated for $3 \mathrm{~h}$ in $\mathrm{HFM}^{7}$ at $37^{\circ} \mathrm{C}$, and germ tubes elongated to about $50 \mu \mathrm{m}$. Time-lapse photomicrography was initiated just after hypha formation for $3 \mathrm{~h}$ and the change of the incubation medium to HFM4. The process of morphological change was observed by a Nikon TMD inverted phase-contrast microscope with a Plan $\times 20 \mathrm{BM}$ objective lens. Cells were photographed at $15 \mathrm{~min}$ intervals.

Observation of microtubules and microfilaments. Pre- 

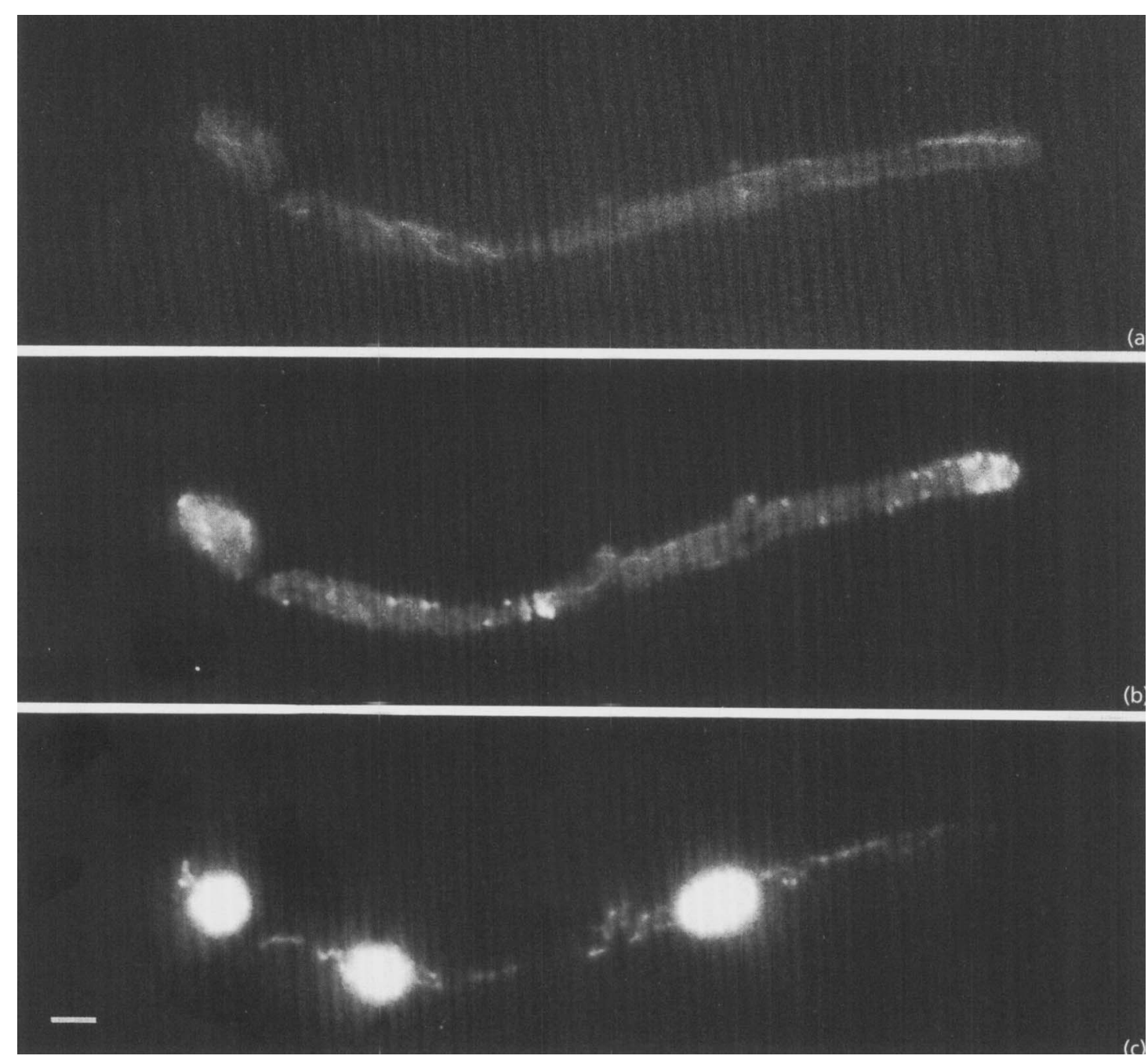

Fig. 3. Triple staining of a germ tube of $C$. albicans IFM 40009, showing microtubules, microfilaments and actin granules, and nuclei. Cells were incubated for $3.5 \mathrm{~h}$ in HFM7 at $37^{\circ} \mathrm{C}$ and then fixed. (a) Staining with anti-yeast-tubulin antibody and FITC-conjugated secondary antibody, showing microtubules; (b) staining with Rh-phalloidin, showing microfilaments and actin granules; (c) staining with DAPI, showing nuclei. Bar, $2 \cdot 5 \mu \mathrm{m}$.

incubated yeast cells were incubated in HFM7 using poly-Llysine-coated plastic Petri dishes at $37^{\circ} \mathrm{C}$ for $2 \cdot 5 \mathrm{~h}$. Medium was subsequently changed to HFM4 and cells were incubated for $30 \mathrm{~min}$, fixed with $4 \%$ paraformaldehyde in $5 \%$ DMSOPBS (PBS containing $0.8 \% \mathrm{NaCl}, \quad 0.02 \% \quad \mathrm{KCl}, \quad 0.29 \%$ $\mathrm{Na}_{2} \mathrm{HPO}_{4} .12 \mathrm{H}_{2} \mathrm{O}$ and $0.02 \% \mathrm{KH}_{2} \mathrm{PO}_{4}$, adjusted to $\mathrm{pH} 8.2$ with $3 \mathrm{M} \mathrm{NaOH}$ ) for $30 \mathrm{~min}$ at $37^{\circ} \mathrm{C}$ and $1 \mathrm{~h}$ at room temperature. Fixed cells were washed twice in $5 \%$ DMSO-PBS $(\mathrm{pH} \mathrm{7.2).}$

These cells were stained by monoclonal anti-yeast-tubulin YOLI/34 IgG (Serotec) and affinity-purified FITC-conjugated anti-rat IgG (Jackson Immunoresearch Laboratories) for tubulin labelling, by tetramethylrhodaminyl (Rh-)phalloidin (Molecular Probes) for observation of F-actin (microfilaments and actin granules) and by 4',6-diamidino-2-phenylindole (DAPI, Sigma) for nuclei. The triple-stained cells in the Petri dish were observed and photographed with an epi-illumination fluorescence microscope-photometer SPM-RFL-II (Nikon), according to Yokoyama et al. (1990).

\section{RESULTS}

\section{Change from hyphal to yeast growth elicited by external $\mathrm{pH}$}

For all yeast cells preincubated in YPD, germination was observed within $60 \mathrm{~min}$ after inoculation into HFM7 at $37^{\circ} \mathrm{C}$. Extension of germ tubes continued for $24 \mathrm{~h}$ in this medium (Fig. 1; c, i). When germ tubes were incubated for the first $3 \mathrm{~h}$ in HFM7 ( $\mathrm{pH} 7$ ) and incubated for $2 \mathrm{~h}$ (Fig. 1 ; a, ii) or $6 \mathrm{~h}$ (Fig. 1 ; b, ii) after external $\mathrm{pH}$ was converted from 7 to 4 at $37^{\circ} \mathrm{C}$, the elongation of apical cells stopped and buds appeared on the apical cell and hyphal cells (Fig. 1; a, ii; b, ii; c, ii). These observations show that this medium supported hyphal growth for a long time; despite the presence of $4 \%$ serum, the extension of hyphal cells did not continue at $\mathrm{pH} 4$.

Time-lapse microphotography was used to observe the 

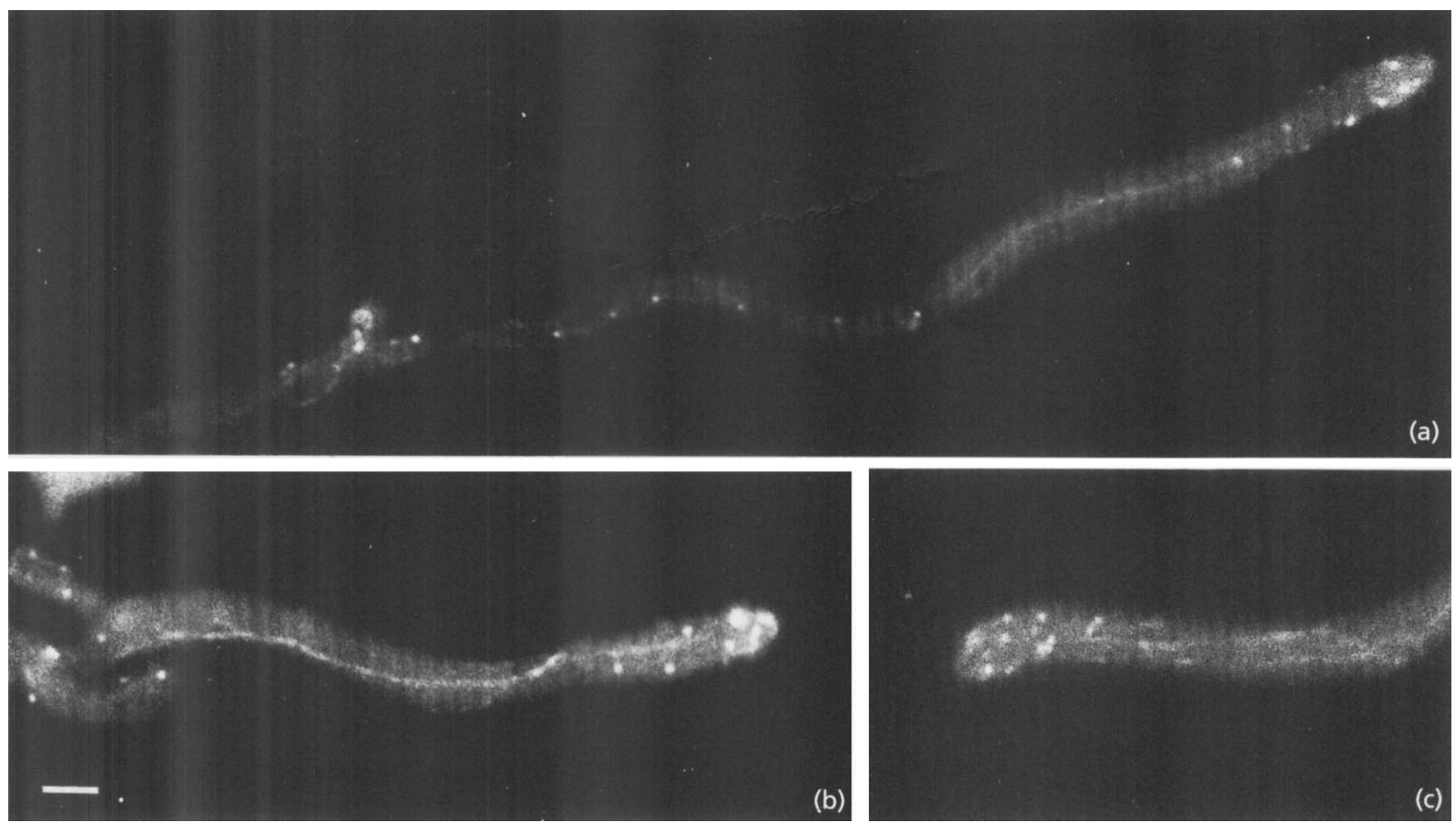

Fig. 4. Rh-phalloidin staining of a germ tube of C. albicans IFM 40009, showing the location of actin granules, long microfilaments (a, b), a network of microfilaments (c) and the location of actin granules on a lateral bud (a). Bar, $2 \cdot 5 \mu \mathrm{m}$

growth conversion progress. Fig. 2 shows inhibition of the extension of the apical hypha within $30 \mathrm{~min}$. The first daughter cell $\left(\mathrm{D}_{1}\right)$ produced the second daughter cell $\left(\mathrm{D}_{2}\right.$, Fig. 2, $90 \mathrm{~min}$ ) simultaneously with, or slightly after, the mother cell $(\mathrm{M})$ produced another daughter cell $\left(\mathrm{MD}_{2}\right)$ (Fig. 2, $90 \mathrm{~min}$ ). This is characteristic of yeast growth. During hyphal growth, the daughter cells always produced other daughter cells faster than the mother cells produced other daughter cells. The inhibition of hyphal extension was observed within $30 \mathrm{~min}$ and yeast growth appeared $75 \mathrm{~min}$ (one generation time) after change in external $\mathrm{pH}$.

\section{Effect of external pH on the distribution of microtubules, microfilaments and actin granules}

Microtubules, microfilaments and nuclei were observed in hyphal cells incubated in HFM7 medium at $37^{\circ} \mathrm{C}$ (Fig. 3). Microtubules were widely distributed in the cytoplasm (Fig. 4a) and microfilaments were observed in growing hyphae (Figs 3b, 4). Long microfilaments were distributed along the lines of cell growth (Fig. 4a, b) and a network of microfilaments was observed in the tips of apical cells, often connected with actin granules in HFM7 medium at $37^{\circ} \mathrm{C}$ (Figs $3 \mathrm{~b}, 4 \mathrm{c}$ ). Actin granules were localized at the tips of apical cells and septum-forming sites (Figs 3b, 4). When the external pH was changed from 7 to 4 , microtubules were observed in the hyphal cell within $30 \mathrm{~min}$ at $37^{\circ} \mathrm{C}$ (Fig. 5a). This distribution of microtubules was the same as in hyphal growth (Figs 3a, 5a). Microtubules distributed regularly according to nuclear migration and the cell cycle. The decrease of external $\mathrm{pH}$ did not affect microtubules directly, but long microfilaments disappeared from hyphal cells within $30 \mathrm{~min}$ after changing the external $\mathrm{pH}$ at $37^{\circ} \mathrm{C}$ (Fig. 5b). Localization of actin granules, concentrated at the tip of apical cells in normal hyphal growth (Figs 3b, 4), was not observed (Fig. 5b). Rather, actin granules were dispersed throughout the apical cells and rearranged at the budding and septum-forming sites (Fig. 5b).

We obtained the same results in all four strains used. These results suggest that the effect of low external $\mathrm{pH}$ particularly affects long microfilaments, which disappear from the cytoplasm, and consequently trigger the reversion from hyphal growth to yeast growth.

\section{DISCUSSION}

In our previous paper (Yokoyama et al., 1990), we showed by using a microfilament inhibitor that microfilaments play an important role in the elongation of apical cells and hyphal growth. In this work we attempted to elucidate the role of microfilaments in fungal morphogenesis.

By using time-lapse microphotography (Fig. 2), we observed a change of hyphal to yeast growth at a low external $\mathrm{pH}(\mathrm{pH} 4)$, although the medium contained serum. Microtubules were distributed in the cytoplasm in a similar fashion as during hyphal growth; however, long microfilaments disappeared from the cytoplasm within 30 min due to the change of external $\mathrm{pH}$ (Fig. 5b). These distributions coincided with the result obtained by using 

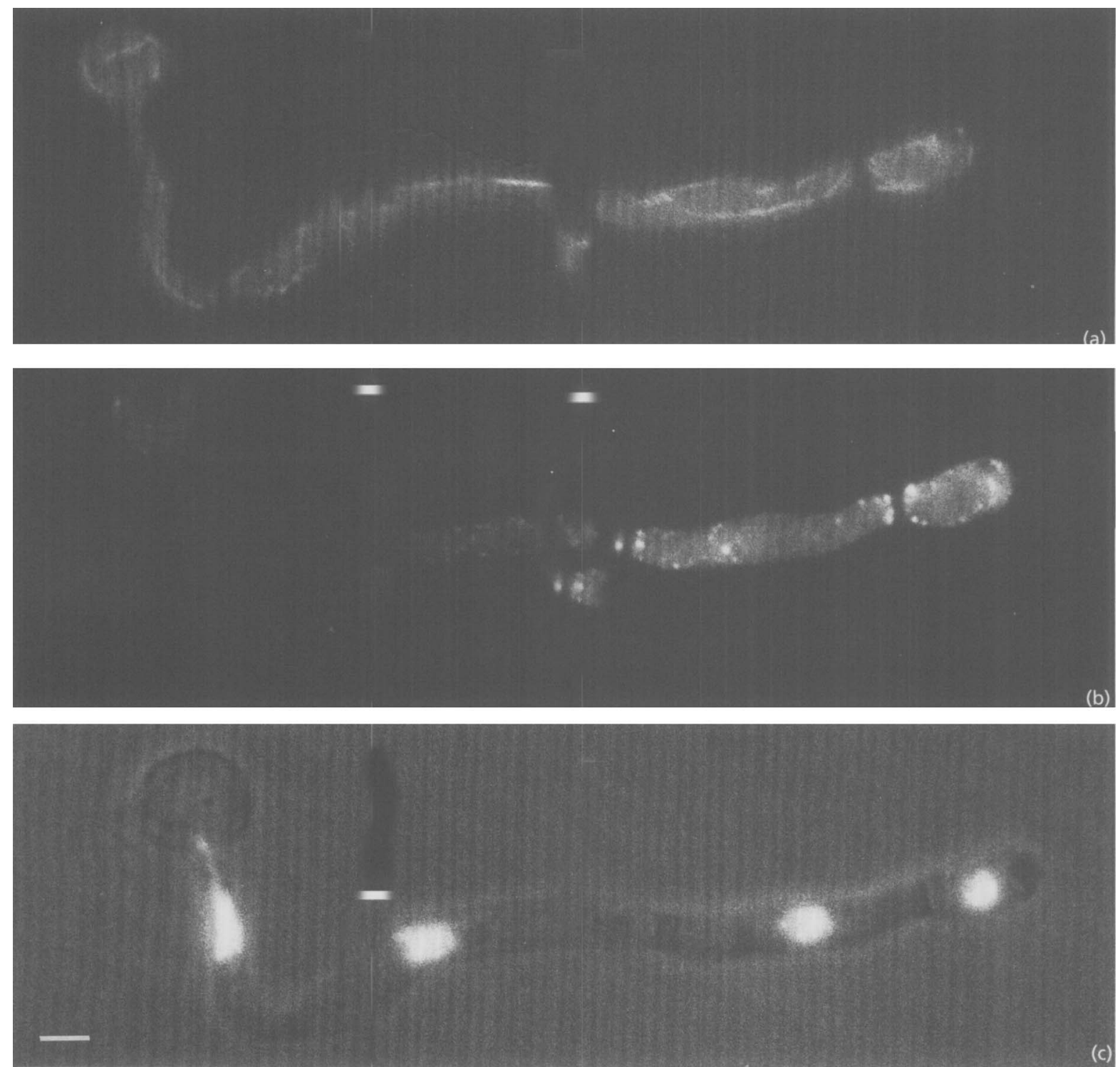

Fig. 5. Triple staining of germ tube of $C$. albicans IFM 40009 at an external pH of 4 . Cells were incubated for $3.5 \mathrm{~h}$ in HFM7 at $37^{\circ} \mathrm{C}$ and the medium then changed from HFM7 to HFM4 at $37^{\circ} \mathrm{C}$. Cells were fixed after 30 min incubation in HFM4 medium. (a) Staining with anti-yeast-tubulin antibody and FITC-conjugated secondary antibody; (b) staining with Rh-phalloidin; (c) staining with DAPI. Microtubules were distributed normally in filamentous cells (a); however, long microfilaments disappeared (b). Bar, $2 \cdot 5 \mu \mathrm{m}$.

a microfilament inhibitor (Yokoyama et al., 1990). These results show that a low external $\mathrm{pH}$ affects microfilaments and thus the mode of growth changes to yeast growth as a result of depolymerization of microfilaments. The change in distribution of actin granules was also similar to that found after using a microfilament inhibitor.

It has been reported that glucose, but not $\mathrm{pH}$, plays an important role, in directly regulating dimorphism in $C$. albicans (Pollack \& Hashimoto, 1987): germ tubes were induced by proline or absence of glucose when the $\mathrm{pH}$ was between 3 and 9. HFM7 medium (containing $0.5 \%$ glucose) induced germ tube formation $(100 \%$ of preincubated yeast cells) and HFM4 inhibited it at $37^{\circ} \mathrm{C}$, which make these media favourable for the study of dimorphism of this fungus. In other studies on $\mathrm{pH}$ regulated dimorphism, it has been reported that the formation of buds or germ tubes (Kaur et al., 1988; Kaur \& Mishra, 1991) and induction of germ tube formation is accompanied by a steep rise in internal $\mathrm{pH}$ and activity of $\mathrm{H}^{+}$-ATPase (Stewart et al., 1988, 1989). Recently, Gupta \& Prasad (1993) reported that levels of plasma membrane $\mathrm{H}^{+}$-ATPase do not change during growth and morphogenesis of this fungus. 
$\mathrm{Ca}^{2+}$ and calmodulin have been reported to be involved in differentiation of fungi such as Ceratocystis ulmi (Muthukumar \& Nickerson, 1984), Dictyostelium discoideum (Lydan \& O'Day, 1988), Physarum polycephalum (Uyeda \& Furya, 1986) and yeast (Muthukumar et al., 1987). Protein phosphorylation is also reported to be involved in the growth and differentiation of Mucor (Orlowski \& Sypherd, 1978), D. discoideum (Sinclair \& Rickwood, 1985) and P. polycephalum (Fronk \& Toczko, 1987). Recently, it has been reported that $\mathrm{Ca}^{2+}$ and calmodulinmediated protein phosphorylation play a role in germination of Metarizizium anisopliae (St Leger et al., 1989) and C. albicans (Paranjape et al., 1990).

External $\mathrm{pH}$ may affect internal $\mathrm{pH}$, concentration of $\mathrm{Ca}^{2+}$ and activity of calmodulin, triggering depolymerization or polymerization of microfilaments. Microfilaments support the assembly of actin granules that probably participate in cell wall synthesis and may induce morphological changes as a result.

\section{REFERENCES}

Buffo, J., Herman, M. A. \& Soll, D. R. (1984). A characterization of pH-regulated dimorphism in Candida albicans. Mycopathologia 85, 21-30.

Fronk, J. \& Toczko, K. (1987). Changes in the phosphorylation of non-histone proteins during differentiation of a lower eukaryote Physarum polycephalum. Biocbem Biophys Res Commun 142, 188- 193.

Gupta, P. \& Prasad, R. (1993). Levels of plasma membrane $\mathrm{H}^{+}$ATPase do not change during growth and morphogenesis of Candida albicans. FEMIS Microbiol Lett 106, 165-170.

Kaur, S. \& Mishra, P. (1991). Dimorphism-associated changes in plasma membrane $\mathrm{H}$ - ATPase activity of Candida albicans. Arch Microbiol 156, 412-415.

Kaur, S., Mishra, P. \& Prasad, R. (1988). Dimorphism-associated changes in intracellular $\mathrm{pH}$ of Candida albicans. Biocbim Bioptys. Acta 972, 277-282.

Lee, K. L., Buckley, H. R. \& Campbell, C. C. (1975). An amino acid liquid synthetic medium for the development of mycelial and yeast forms of Candida albians. Sabouraudia 13, 148-153.

Lydan, M. A. \& O'Day, D. H. (1988). Differential developmental functions for calmodulin in Dictyostelium: trifluoperazine and R24571 both inhibit cell and pronuclear fusion but enhance gamete formation. Exp Cell Res 178, 51-63.

Muthukumar, G. \& Nickerson, K. W. (1984). Ca(II)-calmodulin regulation of fungal dimorphism in Ceratocystis ulmi.J Bacteriol 159, 390-392.

Muthukumar, G., Nickerson, A. W. \& Nickerson, K. W. (1987). Calmodulin levels in yeasts and filamentous fungi. FEMS Microbiol Lett 41, 253-255.

Orlowski, M. \& Sypherd, P. S. (1978). Regulation of translation rate during morphogenesis in fungus Mucor. Biochemistry 17, 560-574.

Paranjape, V., Gupta Roy, B. \& Datta, A. (1990). Involvement of calcium, calmodulin and protein phosphorylation in morphogenesis of Candida albicans. J Gen Microbiol 136, 2149-2154.

Pollack, J. H. \& Hashimoto, T. (1987). The role of glucose in the $\mathrm{pH}$ regulation of germ-tube formation in Candida albicans. J Gen Microbiol 133, 415-424.

St Leger, R., Roberts, D. W. \& Staples, R. C. (1989). Calcium and calmodulin-mediated protein synthesis and protein phosphorylation during germination, growth and protease production by Metarbizium anisopliae. J Gen Microbiol 135, 2141-2154.

Sinclair, J. H. \& Rickwood, D. (1985). Major changes in phosphorylation of chromatin associated non-histone proteins accompany development in slime mold Dictyostelium discoideum. Biochem J 229, 771-778.

Stewart, E., Gow, N. A. R. \& Bowen, D. V. (1988). Cytoplasmic alkalinization during germ tube formation in Candida albicans. I Gen Microbiol 134, 1079-1087.

Stewart, E., Hawser, S. \& Gow, N. A. R. (1989). Changes in internal and external $\mathrm{pH}$ accompanying growth of Candida albicans: studies of non-dimorphic variants. Arch Microbiol 151, 149-153.

Uyeda, T. Q. P. \& Furya, M. (1986). Effects of low temperature and calcium on microfilament structure in flagellates of Physarum polycephalum. Exp Cell Res 165, 461-472.

Yokoyama, K. \& Takeo, K. (1983). Differences of asymmetrical division between the pseudomycelial and yeast forms of Candida albicans and their effect on multiplication. Arch Microbiol 134, 251-253.

Yokoyama, K., Kaji, H., Nishimura, K. \& Miyaji, M. (1990). The role of microfilaments and microtubules in apical growth and dimorphism of Candida albicans. J Gen Microbiol 136, 1067-1075.

Received 27 April 1993; revised 27 August 1993; accepted 10 September 1993. 